INDEPENDENT JOURNAL OF MANAGEMENT \& PRODUCTION (IJM\&P)

http://www.ijmp.jor.br

v. 12, n. 6, Special Edition ISE, S\&P - November 2021

ISSN: 2236-269X

DOI: 10.14807/ijmp.v12i6.1764

\title{
INFORMATION MODEL OF MATERIAL AND TECHNICAL AND FINANCIAL RESOURCES IN HOUSING IN UKRAINE AND EUROPE: ACCOUNTING AND MANAGEMENT ASPECT
}

\author{
Mariia Gumenna-Derij \\ West Ukrainian National University, Ukraine \\ E-mail:m.derii@wunu.edu.ua \\ Nadiya Khorunzhak \\ West Ukrainian National University, Ukraine \\ E-mail:n.khorunzhak@ukr.net \\ Olena Zharikova \\ National University of Life and Environmental Sciences of Ukraine, \\ Ukraine \\ E-mail:ele0309@ukr.net \\ Viktoriia Rozheliuk \\ West Ukrainian National University, Ukraine \\ E-mail:rozelyk@ukr.net \\ Raisa Tsyhan \\ Kremenchuk Mykhailo Ostrohradskyi National University, Ukraine \\ E-mail:raisaoaa@gmail.com \\ Submission: 8/10/2021 \\ Revision: $9 / 13 / 2021$ \\ Accept: 9/26/2021
}

\section{ABSTRACT}

The purpose of the study is to form an information model of material, technical and financial resources in construction, based on identifying and taking into account the existing initial conditions and developing proposals for their improvement at the level of accounting and management by improving the documentation process. The article examines the relationship between material, technical and financial resources in housing construction. It is proposed to consider the information resource as the main resource, because it has an impact on the formation of all other resources, and therefore, in fact, manages them. The economic indicators for the calculations were obtained by the authors from the website of the State Statistics Service of Ukraine for 2009-2020 in 24 regions of the country, JSC "Information and Analytical Center Liga", "Wikipedia" (Ukraine), forms of annual financial statements of 3 construction organizations. 
DOI: 10.14807/ijmp.v12i6.1764

The potential possibility of the working population of Ukraine to purchase housing by making two hypotheses is calculated. At the junction of these hypotheses, appropriate conclusions are formed regarding the improvement of sources of financing for housing construction. Due to the study of problematic aspects of housing construction, a model of material, technical and financial resources in the context of digitalization has been formed. It is proposed to improve financial and management accounting for the formation of new synthetic and analytical accounts, internal and intermediate management documents and the methodology of financial accounting. In the course of the current research, the method of putting forward and proving (rejecting) hypotheses is used to calculate indicators of the potential of the working-age population to purchase housing for the corresponding period of time. On this basis, a comparison of a number of indicators for the regions of Ukraine was made and the lowest and highest potential opportunity for the purchase of housing was calculated. This will contribute to the renewal of natural resources, the search for alternative resources, saving time, optimizing material costs, attracting new types of monetary units (virtual funds) to the construction industry, the speed of settlements with partners, etc.

Keywords: material resources; technical resources; financial resources; financial accounting; management accounting

\section{INTRODUCTION}

In today's economy, information resources are more important than other types of resources. After all, the efficiency of their use of material, technical and financial resources also depend on their rational management. Information about these resources must be reliable, up-to-date, truthful and convenient for recording and processing data in financial and management accounting and for the formation of financial statements. In addition, such information should not contain a corruption component, but meet the requirements of the law.

In our study, we propose to consider information and other types of resources in terms of such a separate subtype of economic activity as housing, because this industry requires a significant amount of resources. On the other hand, the construction process is long, so the final cost of housing can be influenced by external and internal factors. This is also reflected in the fact that the construction site is not always put into operation on time, according to the established project, construction schedules and phased payment schedules.

Resources involved in housing construction can be affected by natural conditions, the purchasing power of the population, the level of wages, the level of inflation, the index of rising 
DOI: 10.14807/ijmp.v12i6.1764

house prices, the location of the construction site and other factors. All these features of the enterprise affect not only the creation, storage, accumulation and use of enterprise resources, but also their reflection in financial and management accounting, as well as in the formation of financial and social reporting of construction companies.

Therefore, in the process of planning a new construction project, construction materials and equipment are selected, their cost is estimated, the method of payment through the Construction Financing Fund, the Real Estate Fund, Mutual Investment Institutions or other types of calculations that do not contradict the Law of Ukraine "On Investment activity".

In addition, the set of materials and equipment at each stage of construction is different, and therefore accompanied by different primary documents, and financial calculations are conducted with different contractors. Hence, a large number of participants are involved in the construction of a residential building, and therefore it is necessary to constantly exercise internal control over the optimal use of material resources and the veracity of financial calculations through the formation of internal reports.

\section{LITERATURE REVIEW}

In the process of selecting the literature, we got acquainted in detail with the works of authors who studied the importance of information and the effectiveness of its reflection in accounting.

In modern conditions, it is fair to say that the positions of information attribute change. It acquires the characteristics of an independent object, which can exist outside of man and material carrier. Accordingly, there is a need to change approaches to its formation (Semenyshena, Khorunzhak \& Sadovska, 2020a).

Accounting is extremely important for the economy, and therefore its improvement is an important area of research. There are a number of factors associated with the need to continue research and find ways to achieve quality accounting improvements. The most significant of these are the change in management demands arising from the genesis of economic systems, globalization, which requires standardization and unification of accounting, as well as the development of national and international accounting institutions that form its current conceptual framework (Semenyshena, Khorunzhak \& Zadorozhnyi, 2020b).

Peculiarities of information and accounting development in different countries of the world acquire their specific features. They are influenced by the economic situation in the country, and, at the same time, they have a certain impact on the national economy. 
Over the last 4 years, Ukraine's national economy has finally shown long-awaited growth. But these growth rates are too modest, about 3\%. Such fluctuations are almost invisible to the majority of the population due to the low base rate (Palekhova, 2021). But if you compare these indicators in the long run, they will become more noticeable. On the other hand, public policy should be aimed at developing and controlling methods that will affect economic growth.

Economists have successfully stated that the dynamic development of economic entities in terms of accounting implies that the accounting data should include additional analysis of financial accounts together with internal forms of accounting. The study, evaluation and comparison of indicators of programs for economic development, social security and implementation of environmental security require the need to create a single index, i.e. an integrated index of sustainable activity (Osadcha et al., 2020).

The economic stability of the state ensures the efficiency of national enterprises. One of the sectors of the economy that needs state support is housing, which today needs to improve social programs.

The situation on the housing market differs in regions or individual cities due to significant differentiation in their development, which affects the possibility of obtaining affordable housing. The implementation of regional development programs should determine the investment priorities of social protection, in particular the possibility of redemption through the mechanism of renting social housing by internally displaced persons (Alekseyenko, 2021).

We agree with the scientist and believe that a socially responsible construction company can operate only if the national economy is stable and government support for business. However, the construction process itself is not always stable due to the fact that some unplanned operations and delays in the housing construction process may occur.

The construction process is usually the result of the joint efforts of a number of trade contractors on construction of the building. The process is often almost chaotic, even if the work is planned according to industry best practices, and unforeseen events are the rule rather than the exception (Bertelsen \& Nielsen, 1997).

Today, the topic of ecological construction is very relevant in the European Union. Thus, a special structure "Horizon 2020" was created, which is the most important tool for research and innovation in the world. It has a great influence on the construction industry. 
One of the articles deals with the use of materials for energy efficiency and materials that can reuse high waste content. Building materials related to the energy efficiency of nanotechnology can become a hot area of research that is being promoted and funded as Key Assistive Technology-KET. The author notes that $70 \%$ of harmless construction waste is recyclable (Pacheco-Torgals, 2008).

Undoubtedly, housing construction is in constant development throughout Europe, and therefore the topic related to the development of new materials, equipment and financing of housing construction is practical.

The review of European housing markets in 2020 is based on research from 16 countries: Austria, Belgium, Croatia, the Czech Republic, Denmark, France, Germany, Hungary, Italy, Latvia, the Netherlands, Norway, Poland, Portugal, Spain and the United Kingdom. The most expensive country is Norway, averaging $4.043 € / \mathrm{m}^{2}$, which is ahead of the United Kingdom $\left(3,753 € / \mathrm{m}^{2}\right)$ today, which had the highest average cost per square meter in many years. In the centre of Oslo, the price per square meter can exceed $8.000 € / \mathrm{m}^{2}$. The three countries with the lowest price per square meter are Portugal, Hungary and Poland $\left(1.088 € / \mathrm{m}^{2}\right.$, $1,323 € / \mathrm{m}^{2}$ and $1,370 € / \mathrm{m}^{2}$, respectively) (Panorama of the residential markets in Europe).

Ukraine is not included in this analysis, but it should be noted that the cost per square meter is 398.95 euros (UAH 13,231, if the euro exchange rate is 33.1643 as of October 1, 2020), which is lower than in the European Union (LLC "Information and Analytical Centre League").

\section{DATA AND METHODOLOGY}

The information model of material and technical and financial resources provides for the study of each individual resource: material, technical, financial, logistical, material and financial and financial and technical. Each of them is analysed comprehensively and individually. Hence the methods of analysis and synthesis are applied.

The scientific method was used for a literature review of the works of economists in order to establish the achievements of previous research and on their basis proposed their own developments on the importance of information resources and economic vectors of housing development.

The graphical method is effective in estimating the level of the average wage in European countries (calculated in euros), as it allows you to visualize the figures. According to this assessment, Ukraine has the lowest rates, and Iceland - the highest. 
Hypotheses for calculating indicators of the potential ability of the working population to purchase housing for the relevant period of time are proposed. On the basis of which the regions of Ukraine are compared and the lowest and highest potential opportunities for housing purchase are calculated.

Derivative conditions of the information model are revealed and their improvement at the level of accounting and management through improvement of the documentation process is offered. In this regard, the information model of material, technical and financial resources is complete, reflects the real situation in the enterprise and creates a basis for innovation.

\section{RESULTS}

We propose to form an information model of resources in terms of digitalization. We believe that information resources are now the main resources, because true, unbiased, holistic information allows you to manage other types of resources with high benefits for the company. If material, technical and financial resources can be calculated as a percentage (this information, for example, can be taken from the balance sheet), the information resource is difficult to calculate, because it is often informal and there are no precise limits and indicators for its evaluation. Because of this, each company evaluates it in its own way.

The information resource, first of all, is operated by the administration of the enterprise: directors, deputies, accountants, analysts, economists and controllers. It is they who make decisions on the management of information resources in the enterprise. Therefore, the remuneration of accountants and employees of economic departments can be a good assessment of the effective management of information resources. Although this is only a small part of the evaluation system of information resources.

Hence, information resources affect the material, technical, financial. Material resources are currently accompanied by two pressing issues regarding: a) their rational use; b) natural recovery. This raises a number of questions about the alternative search for new materials that will perform either paragraph (a) or paragraph (b), or both.

Technical resources contribute to the improvement of economic processes, and therefore technical resources accelerate the speed: reflection of accounting transactions, the formation of a tree of documentation, preparation of financial statements. Technical resources can be called time-saving resources, because they can quickly meet the needs of mankind for information. 


\section{INDEPENDENT JOURNAL OF MANAGEMENT \& PRODUCTION (IJM\&P)}

http://www.ijmp.jor.br

v. 12, n. 6, Special Edition ISE, S\&P - November 2021

ISSN: 2236-269X

DOI: 10.14807/ijmp.v12i6.1764

Financial resources in Ukraine today are the most problematic resources, as they affect the material support of material and technical resources, which require significant costs. For a more detailed assessment of the sources of financial resources, we propose to consider financial resources on the example of construction companies. It should be noted that several sources in Ukraine are the leading sources of financial resources for construction.

The first is the investment of individual investors who plan to buy a home. However, we believe that it is necessary to hypothesize whether the average Ukrainian can actually buy a house for the average monthly salary. The average monthly salary for 2021 in Ukraine is the lowest among European countries and amounted to - 397 euros (Figure 1).

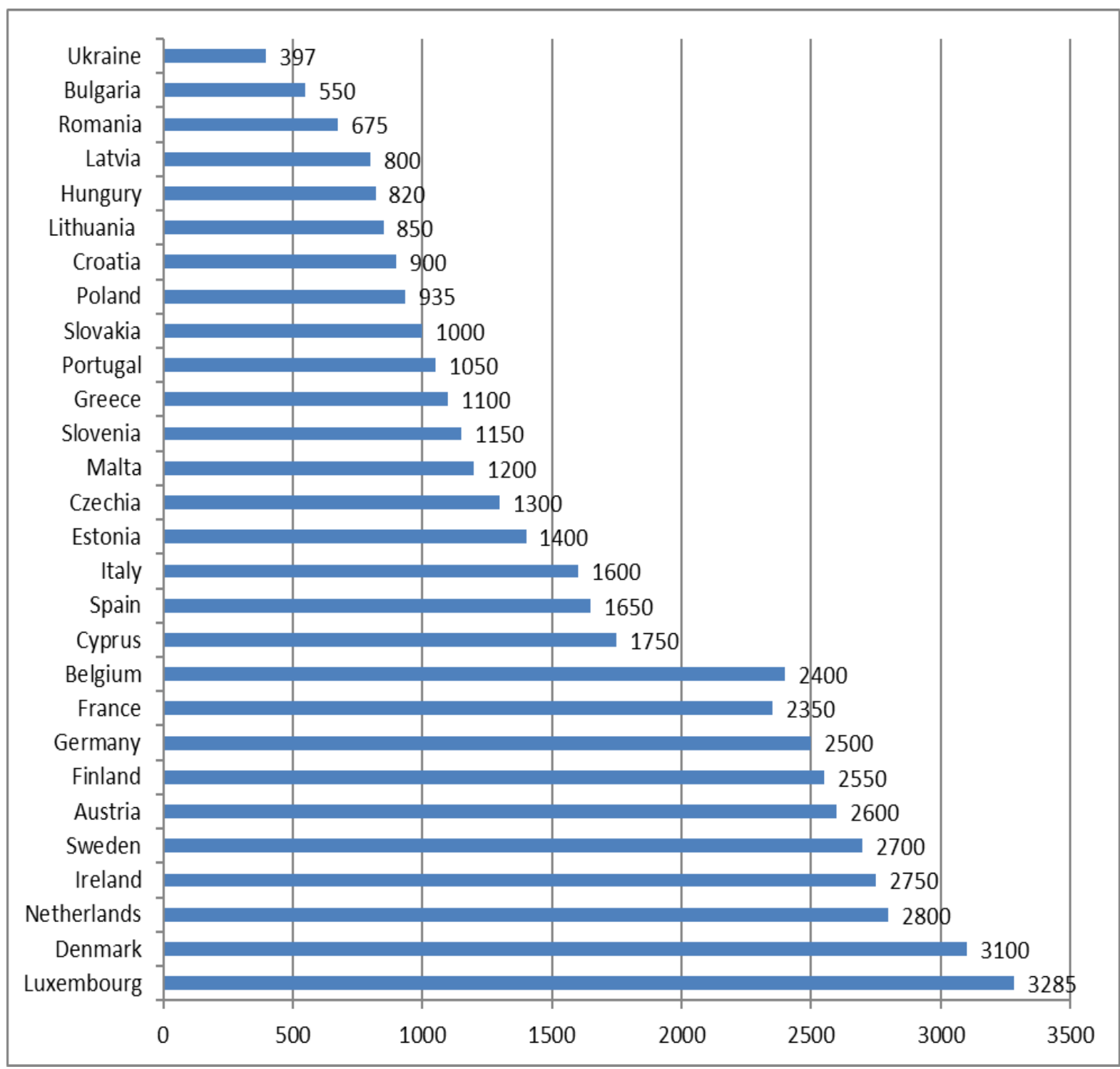

Figure 1: The average monthly salary in European countries in 2021. Source: according to the Average Salary in the European Union

(List of European countries by average wage, 2019). 
Hence, we want to consider hypothesis 1: is it possible for a working person to save money for housing, if he can live on a living wage. We analysed the potential opportunity for working people to buy housing in 24 regions of Ukraine. To do this, the formula for possible savings on the housing of a working person (f. 1):

- Possible savings on housing for working persons = Average salary per month - Subsistence level of working person (f. 1);

- Pos sav. = Av sal. - Sat. min. (f. 1),

where Pos sav. - possible savings of a working person;

Av sal. - average salary per month;

Sub.min. - Subsistence minimum; subsistence level of a working person. This figure for working person in 2019 was 60.57 euros.

In our research, the number of square meters of a one-room apartment is 40 , because this is the average value. Given this number, we calculated the cost of a one-room apartment in the regions of Ukraine. Hence, the formula for calculating the number of years of accumulation of funds for housing (f. 2):

- Number of years of accumulation for housing $=($ The cost of a one-room apartment $/$ Possible savings on housing for a working person) / 12 (f. 2);

- $\quad$ NY acc. hous. $=($ C 1r.d. $/$ Pos sav. $) / 12$

where NY acc. hous. - number of years for accumulation for housing; number of years of accumulation for housing;

- C 1r.d. - the cost of a one-room apartment;

- Pos sav - possible savings on the housing of an able-bodied person;

- the number 12 is the number of month in a year.

We performed the calculation according to these formulas in Table 1, from which the corresponding conclusions are made.

Our study shows that the easiest way to buy an apartment in Kiev, Dnepropetrovsk and Kiev regions.

This is due to the fact that the average monthly salary in these regions is the highest. 
INDEPENDENT JOURNAL OF MANAGEMENT \& PRODUCTION (IJM\&P)

http://www.ijmp.jor.br

v. 12, n. 6, Special Edition ISE, S\&P - November 2021

ISSN: 2236-269X

DOI: 10.14807/ijmp.v12i6.1764

Table 1: Calculation of the potential ability of a working person to buy a one-room apartment in euros (data for 2019)

\begin{tabular}{|l|r|r|r|r|r|}
\hline Regions of Ukraine & $\begin{array}{c}\text { Average monthly } \\
\text { salary in regions } \\
\text { of Ukraine }\end{array}$ & $\begin{array}{c}\text { The cost of } \\
\text { one square } \\
\text { meter }\end{array}$ & $\begin{array}{c}\text { Potential } \\
\text { monthly } \\
\text { savings }\end{array}$ & $\begin{array}{c}\text { The cost of a } \\
\text { one-room } \\
\text { apartment }\end{array}$ & $\begin{array}{c}\text { Number of } \\
\text { years }\end{array}$ \\
\hline Ukraine & 290.82 & 373.62 & 230.24 & 14944.77 & 5.41 \\
\hline Vinnytsia & 260.52 & 360.28 & 199.94 & 14411.26 & 6.01 \\
\hline Volyn & 238.35 & 359.15 & 177.78 & 14365.85 & 6.73 \\
\hline Dnepropetrovsk & 304.12 & 362.24 & 243.55 & 14489.45 & 4.96 \\
\hline Donetsk & 316.74 & 392.44 & 256.16 & 15697.75 & 5.11 \\
\hline Zhytomyr & 236.01 & 328.43 & 175.44 & 13137.37 & 6.24 \\
\hline Transcarpathian & 255.69 & 324.37 & 195.12 & 12974.67 & 5.54 \\
\hline Zaporozhye & 295.01 & 361.86 & 234.44 & 14474.32 & 5.15 \\
\hline Ivano-Frankivsk & 245.16 & 335.97 & 184.59 & 13438.82 & 6.07 \\
\hline Kyiv & 306.55 & 373.15 & 245.98 & 14925.85 & 5.06 \\
\hline Kirovohrad & 229.52 & 317.56 & 168.95 & 12702.24 & 6.27 \\
\hline Luhansk & 239.86 & 358.42 & 179.29 & 14336.84 & 6.66 \\
\hline Lviv & 259.54 & 371.60 & 198.97 & 14864.05 & 6.23 \\
\hline Mykolayivska & 270.45 & 373.08 & 209.88 & 14923.33 & 5.93 \\
\hline Odessa & 261.59 & 357.95 & 201.01 & 14317.92 & 5.94 \\
\hline Poltava & 277.95 & 332.22 & 217.38 & 13288.73 & 5.09 \\
\hline Rivne & 242.23 & 366.97 & 181.65 & 14678.64 & 6.73 \\
\hline Sumy & 236.11 & 350.51 & 175.54 & 14020.26 & 6.66 \\
\hline Ternopil & 222.87 & 350.22 & 162.29 & 14008.91 & 7.19 \\
\hline Kharkiv & 253.17 & 392.70 & 192.60 & 15707.84 & 6.80 \\
\hline Kherson & 225.10 & 339.94 & 164.53 & 13597.74 & 6.89 \\
\hline Khmelnytskyi & 234.56 & 359.59 & 173.99 & 14383.51 & 6.89 \\
\hline Cherkasy & 241.34 & 368.01 & 180.77 & 14720.27 & 6.79 \\
\hline Chernivtsi & 219.40 & 345.84 & 158.83 & 13833.59 & 7.26 \\
\hline Chernihiv & 226.52 & 374.09 & 165.95 & 14963.69 & 7.51 \\
\hline Kyiv city & 432.65 & 436.68 & 372.07 & 17467.31 & 3.91 \\
\hline
\end{tabular}

Source: authors' own development. * - the minimum number of years required to raise funds (excluding inflation and personal living expenses, which will be carried out in further research).

The most difficult is to buy a home in Chernihiv, Chernivtsi and Ternopil regions, because the level of average monthly wages is the lowest here. Hence, Hypothesis 1 is relevant for those regions of Ukraine where the level of average monthly wages is the highest.

Consider Hypothesis 2: how to buy a home if a working person cannot live on a living wage. In addition, given that a working person is dependent on children under the age of 16 , the subsistence level should be counted on them as well. As of January 1, 2019, the subsistence level per child in Ukraine was 63.91 (UAH 2.027 / EUR 31.71).

For example, if the working person has two dependent children under the age of 16, the calculation will be according to the following formula (f. 3):

- Possible savings on the housing of an able-bodied person $=$ Average salary per month - Subsistence level of an able-bodied person - (Subsistence level per child * Number of children) (f. 3); 
- Pos sav.=Av sal. - Sub.min. - ( Sub.min.kid. - Num. kid.)

- $\quad$ where Pos sav. - possible savings of a working person;

- $\quad$ Av sal. - average salary per month;

- $\quad$ Sub.min. - Subsistence minimum; living wage of an able-bodied person;

- $\quad$ Num. kid. - Number of kids.

Let's make a calculation for Kyiv region, because there is the highest level of wages, and for Chernivtsi, where the lowest level of wages.

Possible savings on the housing of a working person per month:

- $\quad$ in Kyiv: $432.65-60.57-(63.91 * 2)=372.08-127.82=244.26$ euros;

- $\quad$ in Chernivtsi: $219.40-60.57-(63.91 * 2)=158.83-127.82=31.01$ euros.

We apply formula 2 to calculate the number of years of accumulation of funds for housing:

- in Kyiv: $(17.467 .31 / 244.26) / 12=5.96$ years;

- in Chernivtsi: $(13.833 .59$ / 31.01) / $12=37.18$ years.

Hence, the working person in Kyiv who has two children will buy a house 2 years later than under Hypothesis 1. The working person in Chernivtsi who has two children will buy a house in 37 years, which is 30 years longer than in previous calculations (for hypothesis 1). This situation is absurd (Table 2).

Table 2: Hypotheses about the financial feasibility of buying a home

\begin{tabular}{|l|l|l|l|}
\hline $\begin{array}{l}\text { № } \\
3 / \Pi\end{array}$ & Hypotheses & $\begin{array}{l}\text { In regions with high wages } \\
\text { for 3-5 years }\end{array}$ & $\begin{array}{l}\text { In regions with low wages } \\
\text { for 6-8 years }\end{array}$ \\
\hline 1. & $\begin{array}{l}\text { Opportunity for a working person to } \\
\text { save money for housing, if he lives on a } \\
\text { living wage }\end{array}$ & Yes & Yes \\
\hline 2. & $\begin{array}{l}\text { How to buy a home if a working person } \\
\text { cannot live on a living wage }\end{array}$ & No & $\begin{array}{l}\text { No (this figure increases to } \\
\text { 36-38 years) }\end{array}$ \\
\hline
\end{tabular}

Source: authors' own development

From the above information we can conclude that it is necessary to improve the conditions of youth lending for families with children. Otherwise, the working person needs to look for another job to receive double the salary.

Often the working population of Ukraine, which has low wages, is forced to go abroad to work to buy housing in a shorter period of time. In addition, it should be noted that the cost of housing will be affected by inflation (Table 3). 
INDEPENDENT JOURNAL OF MANAGEMENT \& PRODUCTION (IJM\&P)

http://www.ijmp.jor.br

v. 12, n. 6, Special Edition ISE, S\&P - November 2021

ISSN: 2236-269X

DOI: 10.14807/ijmp.v12i6.1764

Table 3: Analysis of the relationship between consumer prices and average wages with prices for residential buildings in Ukraine for 2009-2020

\begin{tabular}{|c|c|c|c|c|c|}
\hline \multirow[t]{2}{*}{ Indicators } & \multicolumn{3}{|c|}{ Indices } & \multicolumn{2}{|c|}{$\begin{array}{c}\text { Deviation of price indices } \\
\text { for residential buildings } \\
\text { from }+,-\end{array}$} \\
\hline & $\begin{array}{l}\text { consumer } \\
\text { prices }\end{array}$ & $\begin{array}{l}\text { prices for } \\
\text { residential } \\
\text { buildings }\end{array}$ & $\begin{array}{l}\text { average wages } \\
\text { for December of } \\
\text { the current year }\end{array}$ & $\begin{array}{l}\text { consumer } \\
\text { prices }\end{array}$ & $\begin{array}{c}\text { average } \\
\text { wages }\end{array}$ \\
\hline 2009 & 112.3 & 107.8 & 111.6 & -4.5 & -3.8 \\
\hline 2010 & 109.1 & 116.1 & 117.7 & +7.0 & -1.6 \\
\hline 2011 & 104.6 & 118.2 & 116.2 & +13.6 & +2.0 \\
\hline 2012 & 99.8 & 109.5 & 110.6 & +9.7 & -1.1 \\
\hline 2013 & 100.5 & 104.8 & 107.2 & +4.3 & -2.4 \\
\hline 2014 & 124.9 & 111.1 & 110.9 & -13.8 & -0.2 \\
\hline 2015 & 143.3 & 124.6 & 130.4 & -18.7 & -5.8 \\
\hline 2016 & 112.4 & 108.3 & 123.8 & -4.1 & -15.5 \\
\hline 2017 & 113.7 & 115.0 & 135.6 & +1.3 & -20.6 \\
\hline 2018 & 109.8 & 119.6 & 120.5 & +9.8 & -0.9 \\
\hline 2019 & 104.1 & 103.9 & 116.0 & -0.2 & -12.1 \\
\hline 2020 & 105.0 & 107.4 & 115.6 & +2.4 & -8.2 \\
\hline
\end{tabular}

Source: authors' own development based on State Statistics Service of Ukraine, 2009-2020

Consider the indices of consumer prices, prices for residential buildings and average wages for December each year during 2009-2020 (Fig. 2).

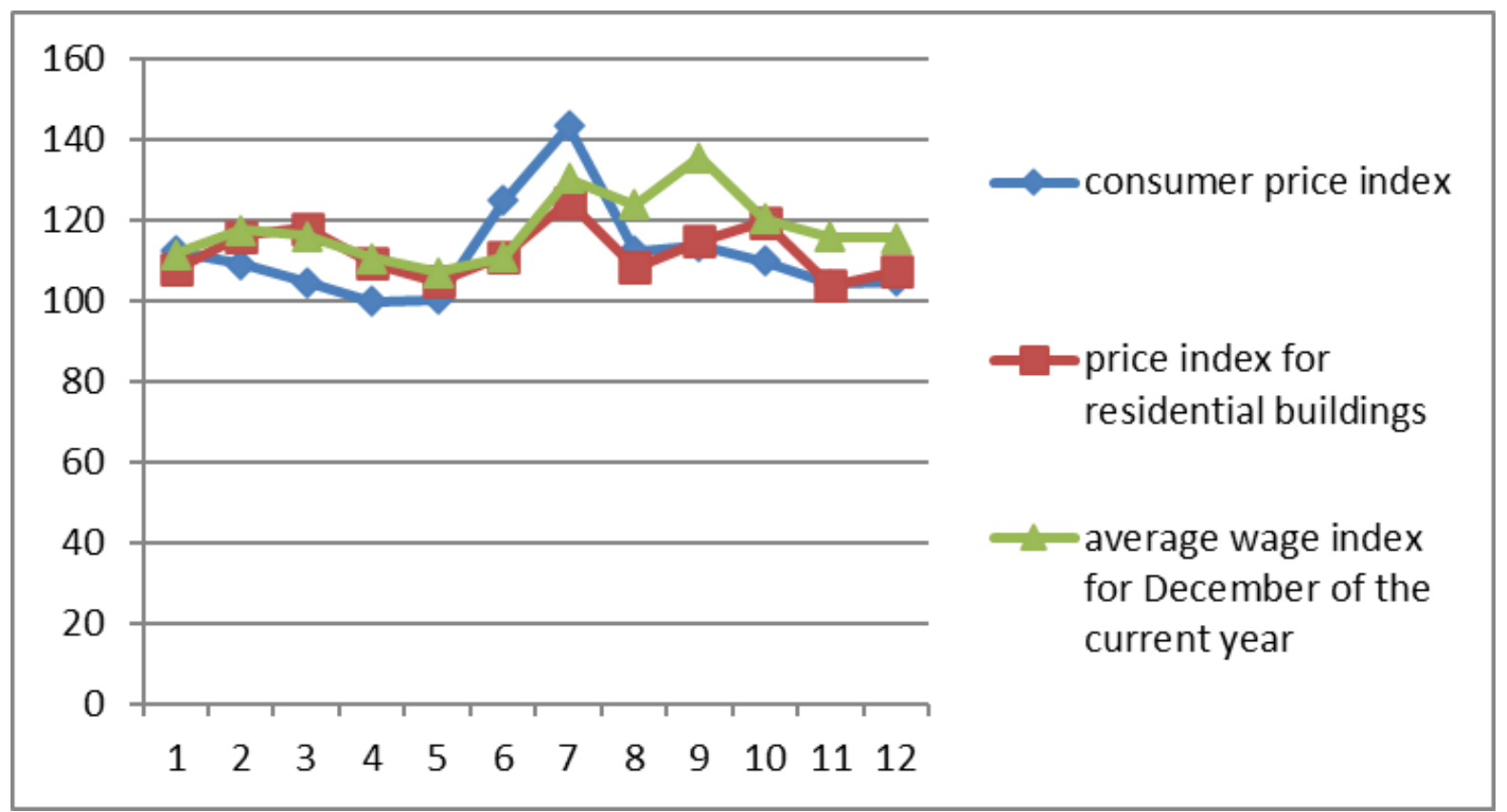

Figure 2: Dynamics of consumer price indices, residential buildings and average wages for 2009-2020

Source: authors' own development based on State Statistics Service of Ukraine, 2009-2020

From Table 3 and Figure 2 it can be concluded that the price indices for residential buildings for the analysed period (2009-2020) were mostly higher than consumer price indices (except for 2009, 2014-2016 and 2019). 
At the same time, house price indices were generally lower than the average wage indices of Ukrainians (except in 2011, when the house price index was 2.0 points higher than the average wage index).

Figure 2 shows that the lines of all three graphs are very close to each other (except for 2011, 2014-2017, where the deviations are higher or lower than 13.6-20.6 points). These years are characterized by serious political changes. Therefore, new reforms are needed to improve the solvency of the population to purchase housing.

There is currently youth lending in Ukraine, but, unfortunately, it is accompanied by a significant number of restrictions, in particular:

- there is a great demand for housing, which forms a large queue, and therefore a larger percentage of those unable to obtain housing;

- some youth programs require buyers to pay almost $50 \%$ of the money immediately;

- if the state after the relevant period of time is not able to repay part of the creditor's interest, the creditor must pay the funds themselves.

Due to this, social or youth lending in Ukraine is accompanied by a number of problems, which in practice are solved, mostly by local authorities, i.e. decentralized.

Another problem is the problem of valuation of material and financial resources and its impact on the formation of the final cost of housing. Whether the calculation of housing takes into account the fair value of housing or how the future value of housing affects the lending system.

Hence, material, technical and financial resources are closely interconnected. Previous studies have defined the concepts of material, technical (Humenna-Deriy, 2020a) and financial resources (Humena-Deriy, 2020b). Based on our research, we propose to consider the information model of resources in terms of digitalization. Because of, modelling makes it possible to assess the current economic situation and forecast of the future.

According to Deriy et al (2020), business process modelling is one of the methods to improve the quality and efficiency of the organization. This method is based on the description of the process through various elements (actions, data, events, materials, etc.) inherent in this process. Process modelling describes the logical relationship of all elements of the process from its beginning to completion in the organization.

We agree with the authors and believe that it is necessary to model the main resources and their derived resources in order to identify their main features that affect the process of 
DOI: 10.14807/ijmp.v12i6.1764

digitalization. The newest resources are formed at the junctions of traditional resources (Figure $3)$.

As noted above, these include: material and technical, material and financial, financial and technical. The percentage of use of these resources may be different in each enterprise.

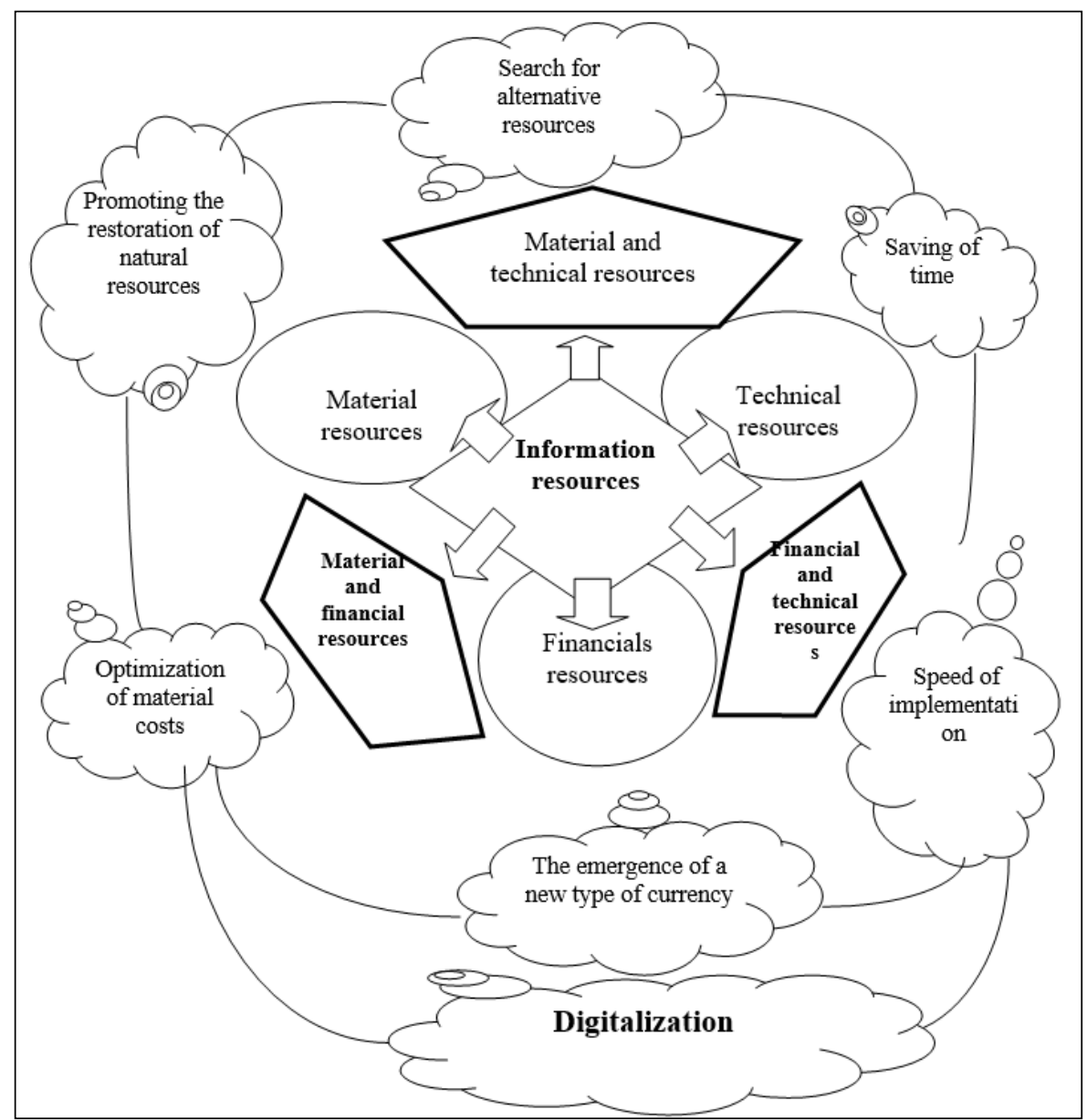

Figure 3: Information model of resources in the conditions of digitalization Source: authors' own development

Usually, it is considered that material resources in construction occupy the largest share. However, material resources interact with technical very often. Similarly, material resources usually need to be valued, so financial resources are closely linked to them. It is now interesting to consider such resources from the standpoint of Balance Sheets of Construction Enterprises.

The balance of Ukrainian enterprises, in general, in terms of assets and liabilities corresponds to the Polish version by about $78-80 \%$ and the European (horizontal format) by about $70-75 \%$. The Ukrainian balance corresponds to less than $70 \%$ of the vertical format of the Euro-balance, which is not regulated in Ukraine (Malyshkin, Bezverkhyi, Kovova, Semenova, etc., 2018). 
If we proceed from the Balance Sheet (Statement of Financial Position) of enterprises and take into account the features of its individual items, they cannot always be attributed to a specific subtype of resources. For example, machinery and equipment are technical resources, but they have a material basis, transfer their value to production costs in the form of appropriate amounts of depreciation, and therefore to some extent they can be called material and technical resources. According to research, Mackenzie (2003) uses tangible assets within the EU to denote assets such as land, buildings, factories and machinery, vehicles, and so on.

This definition does not quite correspond to the Ukrainian interpretation of material resources, under which stocks and goods are considered more. Hence, it is necessary to distinguish: tangible non-current assets and tangible current assets. We believe that the application of the general concept of "material and technical resources" will be relevant here, which will combine tangible non-current assets and tangible current assets. Material and technical resources are the first subspecies of the latest resources.

In the second subspecies, we have identified material and financial resources, because material resources can be valued. The second section of the Balance Sheet reflects current assets, which include: inventories, receivables, cash and cash equivalents, current investments. That is, in fact, all these resources together can be interpreted as "material and financial resources". In addition, the item of the Balance Sheet "Other current assets" is difficult to attribute to material or financial resources, i.e. it is best to identify it as material and financial resources.

The third subspecies of the latest resources include financial and technical resources. This concept is gaining new popularity in the world, as cash payments are now often made in cashless form. On the other hand, the use of crypto-currency changes the functions of cash.

Therefore, to some extent, such changes facilitate the methods of cash settlements. On the other hand, we do not approve of humanity's complete abandonment of cash payments and the complete transition to non-cash payments. Because of, such situation can bring more threats to humanity than benefits. The emergence of cyber-attacks, full computer control of money and payments, the concentration of money centrally - these are the problems that can expect humanity if financial resources are excessively exposed to technical progress.

In the conditions of digitalization all these resources acquire new directions of development. In particular, with regard to: a) material resources, digitalization contributes to the restoration of natural resources; b) material and financial resources, under these conditions, 
INDEPENDENT JOURNAL OF MANAGEMENT \& PRODUCTION (IJM\&P)

http://www.ijmp.jor.br

v. 12, n. 6, Special Edition ISE, S\&P - November 2021

ISSN: 2236-269X

DOI: 10.14807/ijmp.v12i6.1764

contribute to the optimization of material costs; c) financial resources are accompanied by the emergence of a new type of currency; d) financial and technical develop the speed and quality of calculations; e) technical resources provide a resource to save time; f) material and technical resources involve the search for alternative resources. The competitiveness of any construction company depends on the coordinated use of all these resources listed above.

We consider it necessary to consider the accounting and management aspect of the derivative conditions outlined by us, which are interrelated with each other. These include: promoting the restoration of natural resources; search for alternative resources; saving time; optimization of material costs; the emergence of a new type of currency; speed of calculations. Hence, each of these conditions is important for the development of the global economy, however, some, we believe, are more important. To do this, we conducted a study of the resource potential of three construction companies in different regions of Ukraine and determined the percentage of traditional resources of companies based on their Balance Sheet, as well as identified the percentage of new resources (Table 4).

Table 4: Resources of construction companies based on the data of their balance sheets (as a

\begin{tabular}{|l|c|c|c|c|}
\hline Resource & Enterprise 1 & Enterprise 2 & Enterprise 3 & Average value \\
\hline \multicolumn{5}{|c|}{ Traditional resources } \\
\hline Technical & 60.80 & 78.05 & 56.92 & 65.26 \\
\hline Material & 10.90 & 6.50 & 0.35 & 5.92 \\
\hline Financial & 28.30 & 15.45 & 42.74 & 28.83 \\
\hline Together & 100.00 & 100.00 & 100.00 & 100.00 \\
\hline \multicolumn{5}{|c|}{ The latest resources } \\
\hline Material and technical & 35.85 & 42.28 & 28.63 & 35.59 \\
\hline Material and financial & 19.60 & 10.97 & 21.54 & 17.37 \\
\hline Financial and technical & 44.55 & 46.75 & 49.83 & 47.04 \\
\hline Together & 100.00 & 100.00 & 100.00 & 100.00 \\
\hline
\end{tabular}

Source: development of the authors using the balance sheets of individual construction companies in Ukraine

We identified the technical resources of the enterprise on the basis of the result of section 1 of the Balance Sheet. This includes non-current assets. Material resources include stocks, goods. The financial includes cash and cash equivalents, receivables, deferred expenses. However, some items of the Balance Sheet are consolidated and cannot be attributed to one or another resource, as they can belong to two groups of resources at the same time. In particular, this applies to the item "Other current assets" (line 1190 of the Balance Sheet (Statement of financial position).

The data in Table 3 show that the structure of traditional resources of construction companies is dominated by technical resources. In our case, they occupy from $56.92 \%$ to 
$78.05 \%$ (average value $65.26 \%$ ), i.e. from more than half and up to three quarters of all traditional resources. Material resources occupy in the Balance Sheets of construction enterprises from $0.35 \%$ to $10.90 \%$ (average value of $5.92 \%$ ), i.e. from less than a hundredth to a tenth. This difference in the share of material resources can be explained by the fact that a number of construction companies can work with the use of toll construction materials or with the purchase of these materials under shadow schemes (without reflecting such operations in the accounting system). Financial resources in the Balance Sheets of construction enterprises range from $15.45 \%$ to $42.74 \%$ (average value $28.04 \%$ ); i.e. from one-sixth of traditional resources to almost half.

If we approach the assessment of the resources of construction companies from the standpoint of the latest resources, the same companies have completely different indicators. Thus, material and technical resources here range from $28.63 \%$ to $42.28 \%$ (average value $35.59 \%$ ), i.e. from more than a quarter to almost half. Material and financial resources by share are slightly less than material and technical resources. They range from $10.98 \%$ to $21.54 \%$ (average $17.37 \%$ ), i.e. from a little over a tenth to almost a quarter. From the standpoint of new resources, the most important group is financial and technical resources. They account for $44.55 \%$ and up to $49.83 \%$ (average value $47.04 \%$ ), i.e. financial and technical resources are in the balance sheet of construction companies from more than four tenths to almost half.

From the analysis conducted in Table 4, we can conclude that the assessment of the resources of construction companies from the standpoint of the latest resources is more accurate.

Each of the resources has a specific impact on each of the conditions of digitalization in more detail. Promoting the restoration of natural resources is rather a derivative of accounting. Because the resources used can be interpreted as a past event, and investment in the restoration of natural resources - as a prospect. At present, a socially responsible enterprise must invest a certain share of profits in the restoration of resources. It is desirable that public authorities in different countries support such enterprise initiatives by reducing taxes or other incentives. Regarding financial and social accounting, if the company invests in the restoration of resources, then these financial investments are reflected in the accounts of financial accounting, as well as in financial and social reporting (if the company is such).

The search for alternative material and technical resources is gaining popularity in housing construction. Accordingly, the accountant must separate certain accounts in synthetic 
and analytical accounting, determine at what cost and by what methods will be assessed material and technical resources, respectively, and prescribe this in the accounting policy of the enterprise. On the other hand, alternative resources are new, and therefore errors may occur in the method of determining technical resources or in the use of material resources. Such costs are reflected in financial and management accounting.

For example, the installation of solar panels on residential buildings is now gaining popularity. But this area of economic activity is innovative, so the experience of installing solar panels on high-rise buildings in Ukraine is insignificant. This may incur additional costs. On the one hand, solar panels are expensive, and on the other - their inefficient installation can lead to additional costs that must be reflected in the account. Accordingly, there is a need for additional internal reports on additional costs.

Consider the situational problem. One month after installing the solar panels, one of them crashed. The cost of repairing a solar panel is 260 euros. Profit before tax is $-65,000,000$ euros. Will the pre-tax profit decrease: 1 ) if the guilty person is identified; 2 ) if the culprit is not identified? (Table 5).

Table 5: Changes in profit before tax

\begin{tabular}{|l|l|l|l|}
\hline No. & Profit before tax: & Euro & Will change \\
\hline 1$)$ & if the guilty person is identified & 65000000 & yes \\
\hline 2$)$ & if the guilty person is not identified. & 64999740 & no \\
\hline
\end{tabular}

Source: development of the authors

As we can see from the problem, the profit before tax will be reduced by 260 euros, if the guilty person has not been identified.

Saving time depends on several factors: quality technical resources in the enterprise, the legal and normative framework and the content of contracts with investors, the psychological qualities of the accountant and staff. These factors can either save time or, conversely, prolong it, and, consequently, affect the size of financial results. Moreover, additional internal management documentation can facilitate the accounting and analytical process, or, conversely, strengthen it. Therefore, we consider it necessary in the accounting policy to prescribe in advance a set of all internal management reports, which will allow you to plan future events and thus save time on recording the facts of financial life.

Optimization of material costs is to define strategies and plan all stages of housing construction. To optimize material costs, it is necessary to analyse previous periods for the receipt, storage and use of material resources, as well as their evaluation. Transactions related 
to damage to property, based on primary and internal documentation, should be considered in detail. After completing the analysis process, it is necessary to make a plan for the optimization of material resources, which indicates the list of resources, their cost, methods of evaluation and timing. In addition, you can create a certain reserve of funds to correct marriages during the construction of housing.

The emergence of a new type of currency virtual money, so far, has no significant impact on the accounting of monetary settlements in the construction industry of Ukraine. Bit coins for home purchase have not gained popularity and currently do not have clear instructions on how to evaluate them in the financial and management accounting of Ukrainian construction companies, as well as how to automate this process of changing exchange rates.

The speed of calculations can be increased only if the following requirements are met: the intellectual abilities and flexibility of the accountant of the construction company, the availability of stable sources of funding and the stability of the domestic and foreign markets. Now Ukrainian construction companies make payments through the Construction Financing Fund and the Joint Investment Institutions. We believe that calculations should now be made through the Real Estate Fund. Unfortunately, this method is used very rarely. However, we believe that it would be effective for both construction companies and investors. This method can speed up the completion of construction work and increase the number of investors. The reflection of such operations involves strengthening the accounting of investments of construction companies

Returning to the model of material, technical and financial resources, we note that it does not identify intangible resources, but their effect may be the same as information, although they, unlike information, can have not only tangible but also direct impact on them. Intangible resources are also closely linked to material, financial and technical resources. After all, for example, the rights to use natural resources or property indicate the likelihood of obtaining a certain financial benefit from the use of specific assets.

\section{CONCLUSIONS}

The results of research show that the most problematic in the construction industry of Ukraine are financial resources, because the two hypotheses that we put forward about the potential ability of the working population to buy housing need to be addressed at the state level. In addition, the formulas for calculating such opportunities take into account the subsistence minimums of the working population and their dependent children. Such 
calculations make it possible to assess the real situation in the country and look for ways to solve them by increasing the amount of wages in some regions of Ukraine and stimulating social lending.

According to the results of the study of the model of material and technical and financial resources, as well as the derived conditions of such resources formed accounting and management principles for the development of additional analytical and synthetic accounts, internal interim management reports to improve business operations in housing. Such proposals relate to the derived conditions of resources from: promoting the restoration of natural resources; search for alternative resources; saving time; optimization of material costs; emergence of a new type of currency (virtual funds); speed of calculations. Each of these conditions is important for the development of national and global economies.

Further research should focus on the logistics of material resources in housing and their impact on financial and management accounting, to reveal the stages of their implementation and the features of the reflection of business transactions in the software of economics, accounting, control and analysis. Due attention should also be paid to the assessment and analysis of the structure of operating costs of construction companies by elements, especially material costs, depreciation costs of technical resources.

\section{REFERENCES}

Alekseyenko, L., Tulai, O, Petrushenko, Y., Kuznietsov, A., \& Derkash, J. (2021). Affordable housing for internally displaced persons: The priorities for investment and development in Ukraine. Investment Management and Financial Innovations, 18(1), 101113. DOI: https://doi.org/10.21511/imfi.18(1).2021.09.

Bertelsen S., \& Nielsen J. (1997). Just-In-Time Logistics in the Supply of Building. International Conference on Construction Industry Development: Buildiing the future Together. Retrieved from https://citeseerx.ist.psu.edu/viewdoc/download?doi=10.1.1.566.5096\&rep=rep1\&type=pdf. Access: 11 March 2021.

Derii, V., Parkhomets, M., Uniiat, L., Kovbasa, O, Hryzovska, L., \& Karabanyk, S. (2020). Modeling business processes based on logistics concepts and quality management system principles. International Journal of Management (IJM), 11(7), 175-188. DOI: https://doi.org/10.34218/IJM.11.7.2020.017.

Eco-efficient construction and building materials research under the EU Framework Programme Horizon 2020. Retrieved from https://core.ac.uk/download/pdf/55627857.pdf. Access: 04 April, 2021.

Freedman, J. Step-by-Step Accounting for a Small Business in Construction. URL: https://yourbusiness.azcentral.com/stepbystep-accounting-small-business-construction16411.html. Access: 05 April, 2021. 
INDEPENDENT JOURNAL OF MANAGEMENT \& PRODUCTION (IJM\&P)

http://www.ijmp.jor.br

v. 12, n. 6, Special Edition ISE, S\&P - November 2021

ISSN: 2236-269X

DOI: 10.14807/ijmp.v12i6.1764

Holm, L. (2018). Cost accounting and financial management for construction project managers. London: Routledge. DOI: https://doi.org/10.1201/9781315147307.

Humenna-Derii, M. (2020a). Definitsiia poniattia «materialno-tekhnichni resursy» ta yikh vzaiemozviazok z inshymy resursamy u budivnytstvi. Visnyk Ternopilskoho

natsionalnoho ekonomichnoho universytetu, 3, 252-265. (in Ukrainian)

Humenna-Derii, M., \& Ivasechko, U. (2020b). Finansovi resursy u zhytlovomu budivnytstvi: oblikovo-zvitnyi aspekt. Svit finansiv, 4, 118-130. (in Ukrainian)

Ibarrondo-Dávila, P., López-Alonso, M., \& Rubio-Gámez, C. (2015). Managerial accounting for safety management. The case of a Spanish construction company. Safety Science, 79, 116-125. DOI: https://doi.org/10.1016/j.ssci.2015.05.014.

Koznova, O. (2021). How much does it cost to build a square meter of housing in Ukraine. Information and analytical center of the League. Retrieved from https://biz.ligazakon.net/news/200829_sklki-koshtu-budvnitstvo-kvadratnogo-metra-zhitla-vukran. Access: 29 January 2021.

List of European countries by average wage. Retrieved from

https://nomadnotmad.com/what-is-the-minimum-salary-in-the-european-union-countries-in2019/. Access: 01 April, 2021.

Makkenzi, V. (2003). Posibnyk Financial Times z analizu ta vykorystannia finansovoi zvitnosti; per. z anhl. Kyiv: Naukova dumka. (in Ukrainian)

Malyshkin, O. I., Bezverkhyi, K. V., Kovova, I. S., \& Semenova, S. M. (2018). Harmonizatsiia bukhhalterskoho obliku ta opodatkuvannia na pidpryiemstvakh Ukrainy v konteksti normatyviv YeS. Kyiv: «Vydavnychyi dim «ArtEk». (in Ukrainian)

Oleksiyenko, L., Tulay, O., Petrushenko, Yu., Kuznyetsov, A. \& Derkash, Ya. (2021). Dostupne zhytlo dlya vnutrishn'o peremishchenykh osib: priorytety dlya investytsiy ta rozvytku v Ukrayini [Affordable housing for internally displaced persons: The priorities for investment and development in Ukraine]. Upravlinnya investytsiyamy ta finansovi innovatsiyi, 18(1), 101-113. DOI: https://doi.org/10.21511/imfi.18(1).2021.09. (in Ukrainian)

Osadcha, O., Pavelko, O., Nakonieczny, J., \& Zinkevych, O. (2020). Motivational Component of National Corporate Social Responsibility: Funding, Accounting and Reporting Aspects. International Journal of Business and Society, 3, 1012-1032.

DOI: $10.33736 /$ ijbs.3308.2020.

Palekhova, V. (2021). Why does Ukrainian economy grow so slowly? Economics and Sociology, 14(1), 28-45. DOI: https://doi.org/10.14254/2071-789X.2021/14-1/2.

Panorama of the residential markets in Europe: key figures (2020). Foyer Global Health, 19 August. Retrieved from https://www.foyerglobalhealth.com/blog/panorama-of-theresidential-markets-in-europe-key-figures/. Access: 12 April, 2021.

Semenyshena, N., Khorunzhak, N., \& Sadovska, I (2020). Evaluation of the adaptability of scientific theories for the development of Accounting Institute. Intellectual Economics, 14(1), 113-129. DOI: https://doi.org/10.13165/IE-20-14-1-07.

Semenyshena, N., Khorunzhak, N., \& Zadorozhnyi, Z.-M. (2020). The institutionalization of Accounting: the impact of national standards on the development of economies.

Independent Journal of Management \& Production, 8, 695-711. 
INDEPENDENT JOURNAL OF MANAGEMENT \& PRODUCTION (IJM\&P)

http://www.ijmp.jor.br

v. 12, n. 6, Special Edition ISE, S\&P - November 2021

ISSN: $2236-269 X$

DOI: 10.14807/ijmp.v12i6.1764

Semenyshena, N., Khorunzhak, N., Lazaryshyna, I., Yurchenko, O., \& Ostapenko, Y. (2021). Accounting Institute: on the Genesis and Impact of Management Revolutions. Independent Journal of Management \& Production, 12(3), s243-s261.

DOI: https://doi.org/10.14807/ijmp.v12i3.1540.

State Statistics Service of Ukraine. Retrieved from http://www.ukrstat.gov.ua/ (in Ukrainian).

This is the Minimum Salary in the European Union (2021 Data - All Countries).

Retrieved from https://nomadnotmad.com/what-is-the-minimum-salary-in-the-europeanunion-countries-in-2019/. Access: 14 April, 2021.

Wiedenhofer, D., Fishman, T., Lauk, C., W. Haas, W., \& Krausmann, F. (2019). Integrating Material Stock Dynamics into Economy-Wide Material Flow Accounting: Concepts, Modelling, and Global Application for 1900-2050. Ecological Economics, 156, 121-133. DOI: https://doi.org/10.1016/j.ecolecon.2018.09.010. 